\title{
Finding the Balance Between Process and Product Through Perceptual Lesson Planning
}

\author{
P. BRUCE UHRMACHER \\ University of Denver \\ BRADLEY M. CONRAD \\ Capital University
}

CHRISTY M. MOROYE

University of Northern Colorado

Background/Context: Lesson planning is one of the most common activities required of teachers; however, since the late 1970s and early 1980s, it has not been a major focus of study, either conceptually or empirically. Although there are recent articles on the topic, much of the current work is specific to examining a particular teaching method or subject area. This essay not only examines the lesson planning process, a neglected area of study, but also puts forward a perceptual or arts-based approach to lesson planning that has not been attended to since Elliot Eisner's essays on objectives.

Purpose/Objective/Research Question/Focus of Study: The purposes of this conceptual paper are is to provide theoretical grounding for perceptual lesson planning; to analytically examine the two current, dominant approaches to creating lesson plans; and to put forward ideas that undergird a fresh approach to creating and analyzing lesson planning.

Research Design: This study consists of a major literature review and a related conceptual argument. We also present qualitative data (a lesson plan with attendant interview material) and preliminary findings from an ongoing study.

Analytic Framework: We use an original analytic framework to discuss the two dominant approaches to lesson planning, the behaviorist and constructivist modes, and to compare them to the perceptual mode. Our analytical categories consist of the following: intentions, process, product, and outcomes. By intentions we mean the aims, goals, or objectives of the lesson plan. The process refers to how the lesson plan is created and what that experience

Teachers College Record Volume 115, 070303, July 2013, 27 pages

Copyright (c) by Teachers College, Columbia University

0161-4681 
is like for the teacher. Product refers to the actual lessons that result from the planning. Outcomes refer to both the anticipated results of the lesson as well as the general kinds of student outcomes desired in the mode of lesson planning.

Conclusions/Recommendations: Perceptual lesson planning may be characterized as engaging teachers' and students senses and creativity; as an artistic endeavor that is joyful in and of itself; as consisting of various stylized products; and leading toward meaningful learning for students and teachers in an environment open to elements of surprise and innovation. Lesson planning may be functional and meaningful to teachers and subsequently their students. Lesson planning could be something teachers enjoy, learn from, and appreciate. Thus, we note that focusing on the process of lesson planning is an important part of education that warrants much more attention.

\section{INTRODUCTION}

Schools worldwide require lesson plans from teachers, a practice many often view as trivial, mundane, or bureaucratic (Crispin, 1991; Glatthorn, 1993). Rarely do public school teachers think of writing lesson plans as something that pushes their creativity or their ability to create meaning for themselves out of the content they are teaching; lesson planning is seen as a necessity, not as a meaningful act (Crispin, 1991; Glatthorn, 1993; Bulkley \& Hicks, 2005). Further, given that formal plans are often required as a means of demonstrating the content covered (via objectives and/or standards), the lesson plan may be construed as having functional rather than inspirational qualities.

Traditionally, curriculum courses focus teachers on lesson planning using two contrasting theoretical frameworks: behaviorist and constructivist. The behaviorist approach, or mode, asks teachers to begin with objectives and/or standards in mind before designing a lesson that will help achieve those ends. This mode is considered "teacher-driven" and generally seen to be successful based on observable changes in student behavior aligned with the specified objectives (Tyler, 1949; Hunter, 1983). The constructivist mode asks that teachers begin with learners in mind, and represents students as actively engaged in constructing their own knowledge by making meaning out of those situations with support from the teacher. Constructivist lesson planning may still align with lesson standards and objectives, but is more "student-driven," and seen to be successful based on both objectives measures and reflection on individual growth (Duckworth, 2006; Schmuck \& Schmuck, 1988; Schon, 1987; Wiggins \& McTighe 2005). These reflections might include student self-reflections on their learning in the form of quick writes, exit tickets, journals, and the like, and/or may include teacher reflections about their students' growth, which may or may not be shared with the students. 
Generally missing from both the behaviorist and constructivist orientations, however, is an explicit concern for the teacher's process of actually creating the lesson; instead, the focus is the lesson plan as product. In particular, the process of lesson planning pays little attention to ideas such as capturing teacher creativity, meaning-making, and invigoration. ${ }^{1}$ While at first glance, attention to these qualities may not seem overly relevant in the lesson planning process, we argue that an engaging lesson planning experience for the teacher is indeed meaningful. Further, we show that these ideas could be brought to the forefront if curriculum leaders and teachers drew in their work on the educational literature and practices derived from the arts (for examples of ideas derived from the arts see: Barone, 2000; Eisner, 2002, 2005; Constantino \& White, 2010; Greene, 1988, 2001; \& Pinar, Reynolds, Slattery, \& Taubman 1995, pp. 567-606). Metaphorically speaking, teaching may be likened to acting, while curriculum development is like playwriting (Martin-Kniep \& Uhrmacher, 1992). In this paper, we invite curriculum developers, instructors who teach curriculum planning, school administrators, and teachers to more deeply engage in the playwriting aspect of teaching.

To accomplish the goal of engaging teachers more deeply in the lesson planning process, we focus on a third mode to lesson planning, a new orientation, which we refer to as perceptual lesson planning, a mode which has its roots in aesthetic and arts-based educational orientations. We use the term perceptual to bring attention to the use of the senses in the experience. The Oxford English Dictionary defines perceptual as, "The process of becoming aware of physical objects, phenomena, etc., through the senses" ("perceptual," 2005). Key to this definition is the lesson planner's interest in highlighting the sensory aspects of planning for and enacting teaching and learning activities. An emphasis on the senses for our coming to know the world is a point well articulated by philosophers (Read, 1966), psychologists (Arnheim, 1989) and educators (Eisner, 1994).

The purposes of our paper then are several. First, we present theoretical grounding for perceptual lesson planning and suggest ways in which it may complement and enhance the traditional typologies for lesson planning of behavioral and constructivist modes. Second, we elaborate upon the two dominant modes to lesson planning we have described ${ }^{2}$ using a comparative analytic lens to distinguish the features of lesson planning we refer to as intentions, process, product, and outcomes. We then use the same analytic lens to discuss the perceptual mode, which may be used either to enhance behaviorist and constructivist lessons, or as an independent alternative. We do not offer analysis and comparison of the two dominant modes to lesson planning to suggest they be replaced with the perceptual mode, but rather to help those who do curriculum work to better understand how the 
purposes and processes of lesson planning may be complemented by a fresh analytical framework that helps reveal the nuances of each mode. Our end goal is to deepen the discussion on this important and required teacher task.

\section{FORM OF INQUIRY AND DATA SOURCES FOR THE RELEVANT LITERATURE}

\section{BEHAVIORIST AND CONSTRUCTIVIST MODES}

Our research began with an examination of the relevant literature on lesson planning. Using ERIC, JSTOR, SAGE, and the Colorado State Interlibrary system, we at first found mountains of data. We determined that much of the material on lesson planning written in the past 30 years was written for a practical audience (e.g., NASSP articles, ASCD publications); was subject specific (e.g., instructional methods for physical education, using Hunter in the English language classroom); or included "how to" articles that detailed how one might design a lesson plan (Schmoker, 2006; Serdyuko \& Ryan, 2007; Wiggins \& McTighe, 2005). We found that a great deal of the empirical and conceptual work around lesson planning took place in the late 1970s and early 1980s (Clark \& Yinger, 1977; Eisner, 1967; Hill, Yinger, \& Robins, 1983; Hunter, 1984; Renzulli, 1988; Shaw, Pettigrew, \& van Nostrand, 1983; see Yinger, 1979, 1980). This is not to say that there are not recent articles (see Jackson, 2009; Roskos \& Neuman, 1995); however, much of this current work is specific to examining one type of method without much consideration for the larger context of lesson planning in general. Spooner, Baker, Harris, Ahlgrim-Delzell, and Browder (2007), for example, conducted a study around the Universal Design for Learning lesson plan method, but do not do so in the context of other planning modes. Sifting through the relevant research, we began to see patterns and distinguished two dominant approaches, or modes, to lesson planning: behaviorist and constructivist. We use the term "mode" to refer to the general orientation or approach, and we note that there are certainly variances within the two categories. However, the majority of the research as well as the methods used in practice may fall under these two broad umbrellas. Within each mode we use the term "method" to refer to specific ways of achieving the mode. The method describes how the mode is interpreted by educators-how it is actualized in a written lesson plan.

\section{ANALYTIC FRAMEWORK}

We created an analytic framework designed to not only highlight major features of the modes of lesson planning, but also to reveal significant subtleties of the lesson planning process that are often overlooked. In 
Table A. Analytic Framework

\begin{tabular}{|l|l|}
\hline Intentions & $\begin{array}{l}\text { Aims, goals, or objectives of the lesson plan and of the teacher operat- } \\
\text { ing with a particular mode }\end{array}$ \\
\hline Process & $\begin{array}{l}\text { The way the lesson is created; the experience the teacher undergoes in } \\
\text { the planning }\end{array}$ \\
\hline Product & Actual lessons that result from the planning - their physical form \\
\hline Outcomes & $\begin{array}{l}\text { Anticipated results of the mode in general and the lesson in particular; } \\
\text { desired student learning or experience }\end{array}$ \\
\hline
\end{tabular}

this way it was our intention to reveal some of the similarities and differences of each mode and to help educators see opportunities in each. Our analytical categories consist of the following: intentions, process, product, and outcomes.

Our framework, like all frameworks perhaps, has advantages and disadvantages. One disadvantage is that categorization is a reductive process that does not always do justice to the richness and complexity of the lesson plans it classifies. Moreover, lesson-planning practice is undoubtedly more complex than what models can generally provide. However, we use this framework because it offers heuristic value. It allows us to see the landscape of lesson planning quickly and clearly. Because it is derived from the literature on lesson planning, it helps explain and clarify the ideas we put forth on the perceptual mode. Finally, providing the categories may serve to help teachers problem solve and think more creatively about lesson planning.

By intentions we mean the aims, goals, or objectives of the lesson plan. While some authors make clear distinctions among these terms, we use each to get at the basic question, what does the teacher want to accomplish? Further, when we discuss intentions, we use broad strokes to indicate the intentions of the mode itself. For example, the intentions of those who tend to operate in the behaviorist mode have a goal of meeting a specific learning objective in a bounded period of time. The intentions of the mode itself are broader and stem from the literature, whereas the intentions of a teacher operating within the mode has intentions that are lesson specific and mirror the general goals of the mode.

By process, we mean how is the lesson plan created and what is that experience like? What are teachers doing, thinking, experiencing, etc. while creating a lesson plan? We also discuss questions teachers generally ask themselves in the process of creating a lesson in each particular mode so as to understand how each form influences the lesson procedures.

By product we mean the actual lessons that result from planning. While it may seem inconsequential to examine what a lesson plan actually looks 
like, we suggest that the physical appearance of a lesson does carry meaning for the teacher not only in the present, but also in the future when teaching the lesson the following year. Therefore, we ask, how does the lesson plan manifest itself materially? What does it physically look like?

Finally, outcomes refer to both the anticipated results of the lesson, as well as the general kinds of student outcomes desired in the mode of lesson planning.

To contextualize these analytical categories, and to bring to life the lesson planning processes, we have also created sample lesson plans using a method derived from each mode. These are located both in the Appendix and at the following link: www.perceptualteaching.org. But before diving in to our comparative analysis, we present the underlying theory of the perceptual mode of lesson planning.

\section{THE PERCEPTUAL MODE OF LESSON PLANNING}

Perceptual lesson planning, which draws largely on the ideas of John Dewey, Elliot Eisner, and Donald Oliver, focuses on the ways in which the lesson planning process itself can be transformed into a meaningful experience for the teacher, and as a consequence, his or her students. Dewey (1938) argues that experience is paramount in education, and we argue that experience is important for all stakeholders, even teachers. We further draw upon Dewey's ideas of a particular kind of experiencethe aesthetic. In his classic book, Art as Experience (1934), Dewey critiques the museum-dominated notion of aesthetic - in short, the idea that aesthetic experiences happen only in museums looking at great works of art-and broadens our understanding by reminding us that the term "aesthetic" is derived from the Greek word aesthetikos, meaning capable of sensory perception. Aesthetic experience refers to a period of time that is characterized by a particular set of qualities, including an enlivened feeling with a heighted sense of perception and the sense that one is riveted to the moment (see Chapter 3 in Dewey, 1938).

We may have an aesthetic experience in all walks of life. We might drink a cup of coffee and appreciate the warmth of the mug, the swirling colors of white cream and black coffee, and the rich earthy aroma. Or we might take a walk in nature and feel the cool breeze while watching an orange-glow sunrise. And if it is true that we can have aesthetic experiences at home and in nature, then we can also have them in schools. Elsewhere we have discussed how teachers may provide the conditions for students to have "aesthetically-oriented experiences"3 and we noted that the result for students would be a richer and deeper educational experience (see Uhrmacher, 2009). We have also conducted a study that suggests that teachers may derive the pleasures of an aesthetic experience through 
lesson planning, the upshot of which are an enlivening of the educational process, creativity, inspiration, and meaning-making (see Moroye \& Uhrmacher, 2009). We use the findings from that study as a springboard for our deepened analysis here.

How might such aesthetic experiences in lesson planning come into being? First, as we have noted, most lesson plans that teachers submit to principals are generally written in a functional form that in various ways emphasizes statements about objectives, standards, activities, and perhaps evaluative procedures. Typed onto white sheets of paper, such lesson plans function as a guide for teachers reminding them of what needs to be done, in what order, and when. This type of lesson plan serves as a cue card.

But we suggest that the form lesson plans take has implications for the kinds of experiences teachers themselves undergo when creating, enacting and reading the lesson plans. Inspirational quotes, decorative borders, an occasional drawing or photograph, and even varied use of fonts provide forms that allow for teachers to have aesthetically oriented experiences. While discussing theatre, Elliot Eisner once put it this way:

The drama within drama is created through the tensions that writers, actors, stage designers, lighting experts, and directors produce. What happens on the stage is the result of a collective effort. What occurs in literary works and in the visual arts is usually the product of individuals. Whether collective or individual, the common function of the aesthetic is to modulate form so that it can, in turn, modulate our experience. (2005, p. 97)

The functional way of writing a lesson plan rarely modulates an experience that inspires or enlivens the educational process. It does not help teachers become creative or find new meaning in what they may be teaching. But perceptual lesson planning allows for such possibilities. As a quick example, placing Einstein's adage that "imagination is more important than knowledge," (Viereck, 1929) in a playful way on a lesson plan might remind an educator to seek creativity as well as knowledge. Note, too, how changing the font of the quotation may also change one's perception of the meaning of the quote:

\section{Jamagination is more important than knowuledge IMAGINATION IS MORE IMPORTANT THAN KNOWLEDGE}

The first type, Old English, harkens to the notion that the quote reveals something discovered long ago and has a timeless quality to it. It is the kind of print we are likely to find in religious services. The second, 
called Showcard Gothic, has a theatrical touch that might remind one of Mel Brooks' comedic movie Young Frankenstein, or perhaps the more recent and popular shows on vampires. In any case, the point, one that the young Steve Jobs well knew when he created the Macintosh computers, is that form (font) matters. Once again, according to Eisner (2005), "To form is to engage in an activity occurring over time, guided by attention to changing qualities whose end is to produce a structure, either temporal or spatial, that gives rise to feeling" (p. 98). The cue-card style of lesson planning does not tend to yield a deep feeling. Perceptual lesson planning, however, offers the possibility of doing so.

One other way to examine the purpose and implications of perceptual lesson planning stems from Donald Oliver's process approach to education (see Oliver \& Gershman, 1989). From this standpoint, we may note that much of what goes on in modern education, lesson planning included, can be examined by contrasting modernity's greatest achievement, technical knowing, with one of its greatest lacks, ontological knowing. The former provides information, the later provides meaning. Both are needed, argues Oliver, but we live at a time in which the technical overly dominates. Thus, modern culture is coming to an end because of its over-reliance on finding "a new technology to repair the machine, not realizing that the limitations inherent in the machine metaphor are themselves at the heart of the problem" (pp. 2-3). Oliver notes that we need "to move outside the limitations of old patterns of thought and gain a broader understanding of the relationship between our conception of technique and of deep culture" (p. 3).

Thus, lesson planning currently refers to the reasonable interest in communicating transferable information and skills. But lesson planning does not need to end there. Ontological knowing, says Oliver, requires that we also consider the "metaphors of organic life and transcendent dance" so that we "come to know with our whole body, as it participates in the creation of significant new occasions-occasions which move from imagination and intention to critical self-definition, to satisfaction, and finally to perishing and new being" $(1989$, p. 3). The reader may note that almost a whole new language is needed to understand and explain ontological knowing, which refers "to a more diffuse apprehension of reality, in the nature of liturgical or artistic engagement" (p. 3). But we do not need to get far afield to recognize Oliver and Gershman's observation that technical knowing has limitations that ontological knowing may overcome. Stated differently, technical (or functional) forms of lesson planning have weaknesses that ontological, or in our language perceptual, lesson planning may overcome. Some combination of the two forms offers a more holistic and meaningful experience. And so we finish this part of the discussion from where we began with attention on the 
kinds of experiences being had by educators. We believe that lesson planning may offer the conditions for teachers to have deeper experiences than they currently do. A deepened sense of satisfaction in planning is a missed opportunity.

In summary, Dewey reminds us to pay attention to experience generally, and to aesthetic experience in particular. Eisner details how form affects experience, and, for the purpose of our discussion, how the form of a lesson plan may affect its percipients. Finally, Oliver calls our attention to ontological knowing, a holistic way of looking at experiences generally that brings into focus and distinguishes the technical and what we would call the perceptual.

\section{ANALYSIS OF THREE MODES: BEHAVIORIST, CONSTRUCTIVIST AND PERCEPTUAL}

We have noted three approaches to lesson planning: behaviorist, constructivist, and perceptual. To provide further analysis of the three modes, we look through the lens of our analytic framework discussed above that includes four categories: intentions, process, product, and outcomes. It may be helpful to keep in mind the kinds of questions teachers generally might ask themselves during the process of planning in each mode. In the behaviorist mode, teachers tend to ask, what activities might students undergo in order to meet the learning objective? In the constructivist mode, teachers tend to ask, what experiences or activities might help me provide ways for students to reach learning goals, to explore the material, and to help me understand their thinking? In the perceptual mode teachers might ask, what inspires me about this topic, and how might I organize meaningful experiences that inspire students to reach learning goals?

Each mode has particular methods that guide teachers. These methods take the form of lesson plan templates such as the Hunter method, EEL Dr. C, and CRISPA, all of which are explained below.

\section{THE BEHAVIORIST MODE OF LESSON PLANNING}

The behaviorist mode is predominantly predicated upon the theoretical ideas of B. F. Skinner (1938) and Madeline Hunter (1983), which often manifest in didactic teaching in the classroom (Moore, 2009). Proponents of the behaviorist mode aim to set goals, develop alternatives, and ultimately judge the effectiveness of the lesson plan based on achievement of desired outcomes and an alteration in student behavior (Yinger, 1980). This mode of lesson planning has also been referred to as objectives-first (Leinhardt, 1983; Morine, 1976; Yinger, 1980; Zahorik, 1975), 
Table B. Comparison of Behaviorist, Constructivist, and Perceptual Modes using the Analytic Framework

\begin{tabular}{|c|c|c|c|}
\hline & \multicolumn{3}{|c|}{ Modes of Lesson Planning } \\
\hline & Behaviorist & Constructivist & Perceptual \\
\hline Intentions & $\begin{array}{l}\text { Teacher develops } \\
\text { objectives to alter } \\
\text { student behavior; } \\
\text { lesson is often } \\
\text { teacher-centered } \\
\text { or driven. }\end{array}$ & $\begin{array}{l}\text { Student-centered with } \\
\text { aim of discovering and } \\
\text { building their own } \\
\text { knowledge and skill; } \\
\text { make authentic con- } \\
\text { nections with students' } \\
\text { worlds. }\end{array}$ & $\begin{array}{l}\text { To engage teachers' and } \\
\text { students' senses, creativity } \\
\text { and imagination; may include } \\
\text { objectives or targets along } \\
\text { with associated meaning } \\
\text { and connections; focused on } \\
\text { interaction among students, } \\
\text { content, and teacher. }\end{array}$ \\
\hline Processes & $\begin{array}{l}\text { Created by teacher } \\
\text { or teacher teams } \\
\text { with specific, mea- } \\
\text { surable outcomes; } \\
\text { can be created in } \\
\text { isolation or by oth- } \\
\text { ers outside of the } \\
\text { classroom context. }\end{array}$ & $\begin{array}{l}\text { Created by teacher or } \\
\text { teacher teams; can be } \\
\text { created in isolation but } \\
\text { must bear particular } \\
\text { students in mind } \\
\text { (cannot be created "off- } \\
\text { site"); planning may } \\
\text { be cyclical but tends to } \\
\text { be linear, multi-step } \\
\text { process. }\end{array}$ & $\begin{array}{l}\text { An artistic endeavor that } \\
\text { relies on creative thinking } \\
\text { and is joyful in and of itself; } \\
\text { conducive to individual or } \\
\text { team planning; may find } \\
\text { inspiration from outside } \\
\text { sources but are created for a } \\
\text { particular context; uses sen- } \\
\text { sory information; ideas evolve } \\
\text { as lesson is created-teachers } \\
\text { find inspiration for teaching } \\
\text { in the process of planning the } \\
\text { lesson. }\end{array}$ \\
\hline Product & $\begin{array}{l}\text { Formalized step by } \\
\text { step lesson plan; } \\
\text { linear process } \\
\text { often with multiple } \\
\text { pre-determined } \\
\text { aspects (anticipa- } \\
\text { tory set, direct in- } \\
\text { struction, practice, } \\
\text { etc.); generally 3-5 } \\
\text { written pages. }\end{array}$ & $\begin{array}{l}\text { Formalized lesson } \\
\text { plan; various templates } \\
\text { or charts and ways of } \\
\text { proceeding that allow } \\
\text { for variations due to } \\
\text { student interests and } \\
\text { understandings (e.g., } \\
\text { EEL DR C); generally } \\
\text { 2-5 written pages. }\end{array}$ & $\begin{array}{l}\text { Various styles (could utilize } \\
\text { behaviorist or constructivist } \\
\text { methods); attention to rhythm } \\
\text { of the experience; multiple } \\
\text { ways to represent the plan; } \\
\text { colorful images, maps, short, } \\
\text { poetic phrases; may be paper } \\
\text { or web-based; format invites } \\
\text { joy, creativity, and inspiration } \\
\text { multiple points of engage- } \\
\text { ment for future revision; ele- } \\
\text { ments of CRISPA or SCOPES } \\
\text { or other aesthetic method. }\end{array}$ \\
\hline Outcomes & $\begin{array}{l}\text { Preconceived; } \\
\text { measurable; spe- } \\
\text { cific to objective. }\end{array}$ & $\begin{array}{l}\text { Preconceived; measur- } \\
\text { able; specific to student } \\
\text { needs and background } \\
\text { knowledge; focus on } \\
\text { transfer to/from life } \\
\text { experience; students } \\
\text { reflect on own learning. }\end{array}$ & $\begin{array}{l}\text { Fosters teacher and student } \\
\text { creativity; meaningful learn- } \\
\text { ing for students and teacher; } \\
\text { open to intrinsic rewards of } \\
\text { teaching and learning; open } \\
\text { to elements of surprise and } \\
\text { student innovation; designed } \\
\text { to foster meaningful expres- } \\
\text { sive outcomes in balance with } \\
\text { predetermined goals. }\end{array}$ \\
\hline
\end{tabular}


Table C. Modes and Methods of Lesson Planning

\begin{tabular}{|l|l|l|l|}
\hline $\begin{array}{l}\text { Mode: } \\
\text { Approach or orientation to } \\
\text { planning }\end{array}$ & Behaviorist & Constructivist & Perceptual \\
\hline $\begin{array}{l}\text { Method: } \\
\text { How the mode is interpreted by } \\
\text { educators and is actualized in a } \\
\text { written lesson plan }\end{array}$ & $\begin{array}{l}\text { M. Hunter } \\
\text { Multiple Menu }\end{array}$ & $\begin{array}{l}\text { Eel Dr C } \\
\text { Understanding } \\
\text { by Design }\end{array}$ & $\begin{array}{l}\text { CRISPA } \\
\text { SCOPES }\end{array}$ \\
\hline
\end{tabular}

rationalist (Brown, 1988), planning by objectives (Tyler, 1949; Walker, 2002), and linear ends-means (Yinger, 1980). Specific examples of some methods include but are not limited to the Madeline Hunter method (1983) and the Multiple Menu method (Renzulli, 1988). This general mode of lesson planning, first offered by Ralph Tyler ${ }^{4}$ and later further developed by Hilda Taba (1962) and Popham and Baker (1970), recommends four steps in planning that include: (a) specifying objectives, (b) selecting learning activities, (c) organizing learning activities, and (d) specifying evaluation procedures. The ultimate goal in this mode of lesson planning is to produce student learning, which is generally defined by behaviorists as a change in a students' behavior that can be assessed by observation or objective measurement (Tyler, 1949). Using our four categories-intentions, process, product, and outcomes-we provide the following analysis:

The intention of the behaviorist mode is for teachers to develop objectives with the purpose of altering student behavior. Specific objectives will vary depending on content area, student ability levels, and other such factors, but they are generally pre-determined and transferrable to other classrooms and contexts; they may be sensitive to general student interests or needs, but most frequently address common goals. The objectives tend to be chosen through consideration of such questions as: What is to be accomplished? How should this task be done? When should the task be done? Objectives are written in behavioral terms and often include who will complete the task (which students), a hierarchy of steps to task completion specified as observable or objectively measured behavior, and clear rubrics or criteria for how the teacher will be able to know if the objectives have been met (Kellough \& Kellough, 2008). These objectives may be teacher created for a group of children or individual children (as in an Individual Education Plan for special education), or they may be mandated by a school or district (i.e., common objectives). The actual lesson is generally teacher driven, although the instructional strategies for accomplishing objectives may vary. State standards are an important element in the behaviorist mode, as they are often used in 
making decisions about the creation of objectives. In this mode a successful lesson is one in which students demonstrate learning of a pre-selected set of objectives specified by the teacher to align with state standards.

The process of creating a behaviorist lesson plan varies depending on the specific method used in this mode of lesson planning, but there are common elements. This mode generally begins with student outcomes in mind and comes to fruition through a linear or step-by-step process. Teachers can write these lesson plans in isolation or in collaboration with other teachers (Lalik \& Niles, 1990), but the focus of the plan is on measurable student learning outcomes that often align with state standards and high stakes tests.

Behaviorist methods result in a product with which most teachers, administrators, and other education professionals are familiar: a formalized, step-by-step lesson plan with strong correlation between learning objectives and learning activities. The actual format of the lesson plan can vary greatly, but they generally have multiple sections that articulate the teacher's procedures for the lesson. For example, the Hunter method heuristic includes a section for objectives, state standards, an anticipatory set, teaching/presenting (also described as input and/or modeling), guided practice/monitoring, closure, and independent practice (Hunter, 1976). These steps tend to be taken in turn by the teacher implementing the lesson plan and addressed in the same way by anyone observing the class. They thus serve as a script—a sequential instructional guide or quick-review heuristic for teachers to use.

Proponents of the behaviorist mode generally seek outcomes that are both preconceived before the actual lesson and clearly measurable through an alteration in one's behavior-students demonstrate learning in a set of conditions. The activities and assessments that measure student learning are defined in accordance with the objectives for the lesson. The experiences of the students are carefully calculated by the teacher so that they can best have opportunity to achieve the learning objective. Along the way, teachers will often monitor student progress through formative assessments, but the measure of objective attainment routinely comes in some form of summative assessment.

\section{THE CONSTRUCTIVIST MODE OF LESSON PLANNING}

The constructivist mode has in large part been influenced by the theoretical work of Piaget (1955), Bruner (1960), and Vygotsky (1931) and focuses on the notion that learners individually discover and build their own knowledge (Anderson, Greeno, Reder, \& Simon, 2000; Brooks \& Brooks, 1999; Gabler \& Schroeder, 2003; Waxman, Padron, \& Arnold, 2001). Learners construct meaning by coalescing knowledge they already 
possess around new information received. Proponents of constructivist methods seek to find ways for students to control some of the learning and activities that occur in a classroom; teacher-focused approaches such as lectures are minimized (Moore, 2009). This mode places great emphasis on multiple ways of understanding (Gardner, 1983), multiple forms of representing knowledge (Eisner, 1994), learning rooted in authentic situations (Wiggins \& McTighe, 2005), and performance assessment (Marzano, Pickering, \& McTighe, 1993). While there are often clear "learning" objectives, this mode diverges from the behaviorist mode in that its focus is on the student rather than the teacher as the central figure in the planning and the operational curriculum.

Though various constructivist methods of lesson planning share the same philosophical underpinnings, the format and process of the lesson plans can vary. For example, Wiggins and McTighe's (2005) Understanding by Design method contains a three-step process that includes identifying results, determining acceptable evidence, and planning learning experiences. DePorter, Reardon, and Singer-Nourie's (1999) EEL DR C method calls for a six-step process that focuses on student learning styles, multiple intelligences and individual motivation. Beside the aforementioned methods, examples of the constructivist mode include but are not limited to the Kodaly method (Boshkoff, 1991); the Moffet and Wagner method (Weiner, 1997); the Science and Technology for Individuals, Societies and the Environment (STISE) method (Park, 1995); the Marzano method (Marzano, Pickering, \& Pollock, 2001); and the Universal Design for Learning (UDL) method (Center for Applied Special Technology, 1998). We will present the ideas that comprise the constructivist mode again utilizing the analytical framework that examines intentions, process, products, and outcomes.

The primary intention of the constructivist mode is to begin with the students in mind so that they can individually discover and build their own knowledge (Anderson et al., 2000; Brooks \& Brooks, 1999; Waxman et al., 2001; Gabler \& Schroeder, 2003). One of the perceived benefits of such lesson planning strategy is that individual strengths, weaknesses, and interests are considered (Moore, 2009). Moreover, constructivist methods aim to connect learning with students' previous experiences and/or knowledge (Kellough \& Kellough, 2008).

Proponents of the constructivist mode may view lesson planning as a cyclical process in which ideas are revisited, but most lesson plans seem to be linear in nature, as mentioned above. While methods exist that are cyclical in nature (Eisner, 1967), most still require a step-by-step thinking process in planning the lesson (Gabler \& Schroeder, 2003). For example, Wiggins and McTighe's (2005) Understanding by Design method begins with 
teachers first identifying some outcome (usually an "enduring understanding") before considering how it will be measured (determining acceptable evidence), and then finally designing the related learning activities.

The product of planning with the constructivist mode is typically a formalized lesson plan. Though the format can differ, and often includes webs or charts, there is generally a formal template in which teachers write their lesson procedures. These templates are often linear in nature but allow some flexibility so as to accommodate for learners' diversions and explorations - to allow the teacher space to account for changes in students' understanding (see Duckworth, 2006).

For example, the EEL DR C method (DePorter et al., 1999) includes sections to Enroll (where a teacher designs a hook for students), Experience (where teachers design experiences for students that create a need to know), Label (where teachers label the concepts embedded in the activity students have undergone), Demonstrate (where opportunity is given for students to connect the experience with new data so they internalize it and make a personal connection to it), Review (where the information is tied to a larger concept or idea), and Celebrate (where learning is connected to a positive celebration). While this method provides a formal template much like behaviorist methods, it differs in that it closely considers the importance of students being able to connect their own experiences/ understandings with the desired learning outcome.

Although proponents of the constructivist mode generally seek outcomes that are preconceived, these methods often also strive to have students transfer information learned into other learning or life situations that are novel or "far transfer." While the outcomes of this mode vary in measurability, constructivist assessments generally include some sort of so-called "authentic assessment" rather than standardized measures. Authentic assessments refer to those that require students' knowledge and skills to engage in a task that is akin to a real-life situation, problem, or scenario. According to Wiggins (1993), they are,

engaging and worthy problems or questions of importance, in which students must use knowledge to fashion performances effectively and creatively. The tasks are either replicas of or analogous to the kinds of problems faced by adult citizens and consumers or professionals in the field. (p. 229)

The experiences of the students are designed to scaffold student learning from what they already know or have experienced to what the desired learning outcome is. Also, students often will be asked to reflect on their learning in the process so they may begin to understand themselves as learners, developing metacognitive awareness. 


\section{THE PERCEPTUAL MODE OF LESSON PLANNING}

As examined earlier, the perceptual mode of lesson planning attends to the experience of the teacher in creating lessons. While the other modes of lesson planning we have described focus on the actual writing of lesson plans as technical and cognitive acts, like writing out instructions, this mode of lesson planning points out that the act of writing the lesson plan could be seen as an engaging and artistic experience in itself. As we have noted we use the term perceptual to describe the kind of sensory and creative activity with which the teacher is engaged; she perceives the environment, the students, the curriculum, the state standards and district requirements, and makes a decision about how best to proceed.

The intentions of the perceptual mode are to engage teachers' and students' senses, creativity, and imagination. The intentions of a teacher operating in the perceptual mode may include instructional objectives or targets, but also would include associated meaning, inspiration and connections. In other words, the intentions are not generally to stop at the prescribed learning destination, but to also explore further roadside attractions, so to speak. Juxtaposing would be a useful tactic in this kind of lesson planning-placing ideas side by side that might not ordinarily be construed in that way. Juxtaposing is a useful strategy, as is placing ideas and skills in a vertical type of curriculum sequence. In essence, intentions are negotiated and may be layered on top of prescribed learning targets to create a rich tapestry of learning opportunities.

What truly distinguishes this mode of lesson planning is the emphasis given to paying attention to the process of writing the lesson. That is, the assumption with perceptual planning is that the experience itself ought to be intrinsically rewarding and joyful. It ought to allow for teachers to appreciate the freedom and flexibility that this mode of lesson planning provides. Moreover, this form of lesson planning seeks to push the teachers' imaginations, which is something they can find rewarding.

The process of the perceptual mode may be seen as an artistic endeavor that relies on creative thinking and is meaningful in and of itself. Just like behaviorist and constructivist modes, it is conducive to either individual or team planning. When working in teams in the perceptual mode, the shared inspiration may lead to improved ideas and "euphoric" moments of inspiration (Moroye \& Uhrmacher, 2009, p. 97). Further, teachers operating in this mode may find inspiration from outside sources but create for a particular context; the process and the lesson may have universal themes and ideas but are exclusive to the particular teacher and class. Further, rather than starting with an objective, the teacher may begin by tapping in to sensory information-a test tube beaker, the rough edges 
of a poetry book, or the soft, cold squish of Play-Doh. These sensory experiences and other ideas evolve as the lesson is created.

The actual product of a perceptual lesson plan may take many shapes and forms. It is a communication tool like the other modes, but also inspires deeper meaning around the learning concept. It may include cues to the teacher regarding the rhythm of the lesson (times of quiet and times of noise, for example), juxtapositions, colorful images, maps, borders, and quotations may remind the teacher to take a meaningful tangent to deepen learning. The product need not be so different from behaviorist or constructivist plans, but it may enhance them to create an accessorized plan of sorts. It may also use innovative language to describe aspects of the learning experience. For example, Susan Hall (1991) wrote a curriculum unit using the extended metaphor of taking a trip and rather than objectives; she called it SCOPES and used such terms as "possible destinations," "suggested itinerary," and "meanderings," which serve as learning targets that exist as possibilities rather than declarative statements. While there is no required form, the perceptual lesson should invite joy, creativity, and inspiration for the time it was created, as well as for future uses and modifications of the lesson.

The outcomes of a lesson created in the perceptual mode must balance preconceived and spontaneous outcomes. Perceptual lesson planning does not abandon sound learning targets, but instead it opens those targets to elements of surprise and student innovation. The goal of this openness is to provide the conditions for meaningful learning and intrinsic rewards for students and teachers alike. We have identified four primary outcomes related to the perceptual process that make this mode unique from other lesson planning modes.

First, a main outcome of this mode of lesson planning is to foster teacher and student creativity. The rationales for why creativity needs to be stressed in educational environments has been discussed in numerous ways, from the demands of the current work force (Senges, Seely Brown, $\&$ Rheingold, 2008) to the centrality of creativity as a way to think generally (Robinson, 2006). Clearly, student creativity ought to be developed. But as we mentioned earlier, we believe that teacher creativity ought to be encouraged as well. When teachers are engaged in the creative process, they find the lesson plan interesting in and of itself (Moroye \& Uhrmacher, 2010), and we believe this creativity translates into classroom processes if for no other reason than the fact that teachers are modeling creativity when they write their lessons.

Second, this mode of lesson planning emphasizes student and teacher meaning-making. That is, there is a concern that both teachers and students find relevance in the content being taught; we often think about 
what the content can bring to those who are learning it. For example, we generally want to increase student proficiency and/or aptitude in mathematics. But, in this case, we ask what those who are learning the content can bring to the subject matter. One answer to this question, by the way, may not be that the student pushes the disciplinary boundaries of math, which would be asking a great deal. Rather, we might consider what each student is uniquely able to bring is his or her own trajectory toward understanding math. Stated differently, there is always a story about how one learns and when such stories are encouraged to be told, then what students bring to the subject of a discipline such as math enhances meaning-making for the student, for the class, and occasionally for society in general. The same may be said for teacher meaning-making. The teacher's story is about the art of teaching disciplinary content, and every teacher has a story to tell, from how to teach the content to one child or to a whole group, from students who are interested in the subject matter to students who do not care, and especially from a technical framework, narrowly prescribed, to an aesthetic conceptual framework that is deep and wide.

Third, this mode of lesson planning emphasizes the idea that the teaching and learning process ought to be intrinsically rewarding. Undoubtedly there are times in which teachers and students will value the outcome that learning activities provide more than the process itself, but this form of lesson planning does focus on the fact that at least some aspects of the educational process ought to be rewarding for the journey undertaken. As we have mentioned throughout this paper, teachers often write their lesson plans for extrinsic reasons (i.e., the principal demands it), but when lesson plans are seen as aesthetic devices as well as functional ones, then lesson planning becomes a worthwhile journey for the teacher for its own sake. In essence, the aesthetically oriented lesson plan becomes a record of the teacher's thinking-of her ideas and inspirations-and that record serves as a meaningful starting point for subsequent years of teaching.

Fourth, decades ago, Elliot Eisner (1967) coined the term "expressive objectives" (later expressive outcomes) to refer to significant classroom activities that are not captured in the notion of objectives. That is, sometimes teachers plan useful and important activities without knowing exactly what the upshot of the activity will become. When teachers decide to take a field trip to the zoo, they may not place their goal in an objective-students will learn the three parts of an ant-but rather teachers know that the field trip is likely to yield all sorts of worthwhile outcomes. This form of lesson planning explicitly allows room for such activities. 


\section{PERCEPTUAL LESSON PLANNING EXAMPLES}

The perceptual mode, like the other modes, does not require a single specific template or format; there are many methods. However, to illustrate a specific application of how this might work, we provide an example out of the CRISPA method (see Moroye \& Uhrmacher, 2009, 2010; Uhrmacher, 2009). CRISPA is an acronym that stands for connections, risk-taking, imagination, sensory experience, perceptivity, and active engagement. Similar to the EEL DR C method, each of these represents an element in the lesson. In contrast, CRISPA does not designate the specific order of the lesson, nor are all six elements required for each lesson plan. In a sense, CRISPA elements are like colors on an artist's palette: available for use when and if they would complement the whole picture.

The example below reveals how a lesson might unfold in a teacher's imagination as she engages in the perceptual mode of planning ${ }^{5}$. The topic is Judy Blume's Tales of a Fourth Grade Nothing, a fourth-grade story about sibling rivalry. Sally, a public school teacher, agreed to participate in a small pilot study by writing this perceptual lesson plan, and she then allowed us to interview her after she created it. Sally created the lesson on Google Docs and we interviewed her on the telephone for 30 minutes. We selected Sally because she had attended a workshop on using a particular method called " 6 Dimensional Teaching and Learning" or CRISPA. Throughout the analysis you will notice attention to connections, risk-taking, imagination, sensory experience, perceptivity, and active engagement (see Moroye \& Uhrmacher, 2009, 2010; Uhrmacher, 2009). As in the behaviorist and constructivist modes, each has associated methods of implementing that mode. So while a Hunter lesson plan is a method to enact the behaviorist mode, a CRISPA lesson plan is a method to enact the perceptual mode.

Sally was an enthusiastic participant in this process and so the reader may wonder about whether all teachers would be so agreeable to the perceptual ideas. Our earlier work would suggest that many teachers are inclined to the perceptual process (see Moroye \& Uhrmacher, 2009, 2010), but our point here is not to showcase eager participants, but rather to reveal what may result when one undergoes perceptual lesson planning. Thus, we encourage readers to pay attention to the kinds of experiences had by Sally when she created the lesson.

\section{INTENTIONS}

Sally's intentions seem to be threefold. About her general aims, she said:

This is what I was thinking about as I created the lesson: I know that I have to teach this book because it is part of my fourth-grade 
curriculum, and I have to teach vocabulary. And, I'm excited about the theme of sibling rivalry. What is sibling rivalry and what is interesting about it for my students? I knew I could make lots of interesting connections for them, and that is where I started-with ideas about how to connect students to the text.

Note that Sally does not frame her goals in behavioral terms-but of course she could. The point is that perceptual lesson planning does not demand that one write behavioral objectives, but she does have a plan in mind. Her primary goal was to connect students with the material: "I remember at the [CRISPA] workshop that we talked a lot about ways to get students pulled into what we were teaching. I like that, and I think it makes sense here as a goal." As Sally works on her actual lesson plans other aims occur to her.

\section{PROCESS}

According to Sally, her next move was to start searching the web: "I was trying to think about sensory experience and started searching for stuff on the web about sibling rivalries and there wasn't a lot. Then what popped in my head is that my son is an only child." She laughs as she asks, "Am I screwing up my son's life? He won't have sibling rivalry." Her next thought was of the song, "Work it Out" by Jurassic 5 and Dave Matthews, and how that applies to her topic of rivalry. "If there's a problem with your family then work it out," she sings. In her search to incorporate sensory experiences for her students, she conjures connections for herself. "My 5-year-old son and I dance to that song." What is interesting to note in Sally's reflections is how the topic she is teaching for class becomes personal for her. This is a point we will return to below. Now, at this juncture, Sally has decided to place a line about music on her lesson plan: "If there's a problem with your family then work it out.' Jurassic [5], featuring Dave Matthews-perhaps play the song if students are interested." She also inserts a small picture of a musical score.

In our interview, Sally adds:

As I was thinking about my only child, I was realizing that my students-many have brothers and sisters and many don't. But they all have to deal with family issues. I wanted students to examine other rivalries. I realized that this might actually be a form of risk-taking. What would it be like for students to talk about their families?

Sally told us that she became quite absorbed in the process of searching for pictures: "I saw pictures of the Williams sisters, Bert and Ernie, and 
I found an article on sibling rivalry. All of this brought in culture too." What we see then, is that as Sally brings in pictures and other material from the web, her thinking about her lesson advances. She started with notion of rivalry and then added nuances to her thinking general thinking-all kids have to work out family issues. Moreover she noted, "Rivalry can be a good thing." At that point Sally realized that she could approach the vocabulary lesson and the theme of family relationships from a single vantage point - a letter of advice from the students to Fudge and Peter. The sequence unfolded around this idea, and she sketched out her steps on the plan: discuss sibling rivalry; draw and pair share about vocabulary words; write an advice letter to either Fudge or Peter and use several of the vocabulary words.

What comes through in our discussion with Sally is that she truly enjoyed creating the lesson. Also, one may see that the way she thought about the intentions of the lesson might be described as "layered" and "nuanced." The intentions built up by juxtaposing her personal life, her students' lives, and the demands of the lesson (reading the text and study vocabulary words). In addition, Sally was motivated as she continued searching the web ("I was inspired by photos I searched for on the web and the song too."). Finally, the general experience for Sally may be described as a sensory one, which caused her to include a sensory experience for her students. "I didn't initially intend to include an activity that had drawing in it," she says, "But, I had so much fun looking for pictures; I decided I wanted my students to engage in drawing - to experience visual interest."

\section{PRODUCT}

Sally's actual lesson plan is filled with meaning for her. She does note that she "would have liked more quotes and a different layout of the lesson, but [she's] limited technologically." Sally said over and over again how much she liked the pictures and the quotations-not only in finding them and placing them on her lesson, but also in looking at them once placed on her product. In regard to the final product, Sally reflects slowly, "I like that I pulled in quotes. I am also pleased with the content. The appearance is exciting. It may not be a work of art, but it's exciting. It's nice to have it serve as more of a compass than a lesson." Further, she noted that next year when she teaches the same text, she will enjoy opening up her file to view the lesson plan. "I think it will be interesting to see if I am inspired by the same things next year!"

When we asked her if she would make any changes she said, "I want to include more of the CRISPA elements. But I wasn't really sure how to start this lesson, so knowing that I could start with connections was super 
helpful. Then when I would wonder what to do next, I could go to the CRISPA palette and another idea would come to me." Sally incorporated connections, risk-taking, sensory experience, and active engagement (which she did not mention but is evident).

\section{OUTCOMES}

Earlier we pointed out that the outcomes of perceptual lesson planning would be increased creativity, meaning-making, intrinsic rewards, and expressive outcomes. We believe that all of these are realized in Sally's creation of a perceptual lesson plan. Although the example provided here is a pilot and needs extended study, Sally spoke to us candidly and openly and for the purpose of illustrating the new mode. She told us how teaching vocabulary is something she has to do but that she is "not terribly inspired by mundane vocab words." So, she decided to have students learn vocabulary through activities related to the story (e.g., writing advice to the main characters). The perceptual lesson helped Sally think creatively about her teaching.

In addition, the various pictures and quotations have deep meaning for Sally. She points out that the perceptual lesson made her think "about sibling rivalry in my own life. This became more about my students and me and not just the text. There was a shift in emphasis." And so, she was not just thinking about the text, but rather the text in relation to her and her students. Said Sally,

I guess the overall point is that the images really helped me broaden my own thinking about the theme of sibling rivalry. Just staring at the photo of the ducks next to the photo of the Mannings is a statement about our life conditions. There is something comforting in that-in knowing that we all share in some struggles and in some triumphs. Maybe a picture really is worth a thousand words! And I think that if the photos helped me, they would certainly help my students!

In regard to making the lesson planning fun and intrinsically rewarding, Sally said,

Oh this totally rejuvenated my belief in the perceptual. It helped me focus on the big idea rather than the objectives. The kids get the same content, but it is done in a more creative way. This was very energizing and fun. It made me excited about teaching the lesson and not just prepared-but interested.

Sally recognizes that the perceptual has the potential to move far afield from what should go on in schools with all of its demands to meet standards, 
to stay on task, to show measurable outcomes and so forth. But this example with Sally reveals how one may use the perceptual in a way that meets school demands as well as teacher interests and satisfaction with the task at hand (that is, writing of the lesson plan).

Finally, Sally also elaborated upon the way the lesson was built up and encouraged her in ways that she did not initially intend. She had not, for example, planned to have a visual activity for her students. As Eisner conceptualized the notion of expressive outcomes (2002), he was focused on the operational curriculum. He wanted to account for the fact that good teaching may veer away from what was initially planned and that good teaching is often improvisational. We would add to Eisner's ideas that expressive objectives may take place in the lesson planning process. In other words, teachers need not always start with objectives. They may start with an image, an inkling, or an inspiration and build out from there.

\section{IMPLICATIONS FOR FUTURE RESEARCH}

The perceptual mode of lesson planning opens a number of corridors to potential future research on curriculum development, lesson planning, and teacher creativity. First, given teacher stress and burnout, it would be worthwhile to capture the experiences of the population of teachers who use perceptual planning, to see whether perceptual lesson planning offers the sorts of opportunities for rejuvenation that we see in our preliminary work.

Second, we suggest that researchers look at how perceptual lesson planning affects classroom activities. What is the difference in the operational curriculum of teachers who use perceptual lesson planning from those who do not? One could examine teachers who use this mode of lesson planning and contrast them with teachers who do not, or one could try to examine teachers who use perceptual lesson planning in some classes, but not in others.

Third, does perceptual lesson planning affect the quality of students' experiences, and if so in what ways? In short, does the potentially deeper experience had by teachers using perceptual lesson planning affect students in terms of their feelings about the classroom activities (in Deweyan terms, is the class more satisfying, which would perhaps encourage students to want to continue learning)? Also, we would recommend studies of how perceptual lesson planning affects student achievement in content areas. We recognize that this avenue of research requires a clear path from perceptual lessons to various types of student test-like events; this path would need to be elucidated in the future to draw the links. Nevertheless, we believe this stream of research offers great possibilities. 
In addition to looking at the perceptual lesson planning process as an independent mode, it would be most interesting to examine how perceptual lesson planning is incorporated by practicing teachers into behaviorist and constructivist lesson plans. We have argued that the perceptual can enhance all lesson planning processes, and future studies could explore this interplay. Finally, a continuation of lesson planning theory would be useful and thought provoking. We have placed our perceptual ideas largely in the tradition of aesthetic ideas elaborated upon by Dewey and Eisner, and we have shown that all experiences have the possibility of becoming aesthetic ones-the lesson planning process included (see Uhrmacher 2009). Dewey (1934) believed that there had to be a tinge of the aesthetic experience for the artist in the creation of an artwork in order for an aesthetic experience to be had by percipients. Is this the case for teachers creating lessons and students experiencing them? To continue this line of theorizing we will explore and elucidate the arc of lesson creation, implementation, and evaluation.

We have also placed our ideas in the theoretic realm of process philosophy as outlined by Oliver and Gershman (1989) and in doing so distinguished the technical from the ontological, or what we might call information-functional versus holistic meaning-making. From this standpoint, we would especially encourage researchers to examine the somatic experiences in the lesson planning process. What kinds of somatic experiences are there? What kinds of relevant somatic experiences could there be? The somatic seems to be an especially grounding energy in ontological ways of knowing and being.

\section{CONCLUSION}

In this paper, we have tried to shed light on issues pertaining to lesson planning that often go unnoticed or overlooked-the significant subtleties. When one does not perceive lesson planning as a functional act alone, it may be invigorating to teacher and students alike while concurrently meeting the requirements of state standards. Lesson planning could be something teachers enjoy, learn from, and appreciate. This stands in contrast to the way teachers are generally taught to do lesson planning. Thus, we note that focusing on the process of lesson planning is an important part of the educational process that warrants much more attention. We can profitably ask such questions as: can teachers find heightened intellectual and aesthetic experiences when engaging in lesson planning? Do these lesson plans result in engaged experiences for students as well? Deep consideration of these questions may lead teachers and students into surprising and rewarding educational territory ripe with possibility for enlivened teaching. 
1. One notable exception is to be found in the work of Eleanor Duckworth. In writing about curriculum materials, she notes that "Instead of expecting teachers and children to do only what was specified in the booklets [of the 1969 elementary science study project], it was the intention of the program that children and teachers would have so many unanticipated ideas of their own about the materials that they would never even use the booklets" (2006, p. 8).

2. We recognize that there are other approaches to lesson planning. However, in this article, we focus on the two approaches most used in K-12 environments today as indicated by the large number of resources and publications in circulation for practitioners that emphasize these orientations.

3. We use this phrase to refer to the process more than the product and to point out that one cannot be forced into an aesthetic experience. At best, the interaction between the qualities of the environment and a person provides the opportunity for an enhanced experience.

4. We note that Tyler's ideas were predicated upon those offered by Franklin Bobbitt, who was the first to offer a two-step process for developing curriculum. These included devising learning objectives and devising educational experiences. Tyler utilized those two steps and added two more - organizing learning experiences and evaluating learning experiences.

5. Sample lesson plans for Tales of a Fourth Grade Nothing are available at httep://www.perceptualteaching.org. We provide a lesson planned with each of the three modes: behaviorist, constructivist, and perceptual.

\section{References}

Anderson, J. R., Greeno, J. G., Reder, L. M., \& Simon, H. A. (2000). Perspectives on learning, thinking, and activity. Educational Researcher, 29(4), 11-13.

Arnheim, R. (1989). Thoughts on art education [Mimeo]. Los Angeles, CA: J. Paul Getty Center for Education in the Arts.

Barone, T. (2000). Aesthetics, politics, and educational inquiry. New York, NY: Peter Lang.

Blume, J. (1972). Tales of a fourth grade nothing. Boston, MA: Dutton.

Boshkoff, R. (1991). Lesson planning the Kodaly way. Music Educators Journal, 78(2), 20-34.

Brooks, J. G., \& Brooks, M. G. (1999). In search of understanding: The case for constructivist classrooms (2nd ed.). Alexandria, VA: ASCD.

Brown, A. (1988). Twelve middle-school teachers' planning. The Elementary School Journal, 89(1), 69-87.

Bruner, J. (1960). The process of education. Cambridge, MA: Harvard University Press.

Bulkley, K. E., \& Hicks, J. (2005). Managing community: Professional community in charter schools operated by educational management organizations. Educational Administration Quarterly, 41(2), 306-348.

Center for Applied Special Technology. (1998). What is universal design for learning? Westfield, MA: Author.

Clark, C. M., \& Yinger, R. J. (1977). Research on teacher thinking. Curriculum Inquiry 7(4), 279-304.

Costantino, T., \& White, B. (Eds.). (2010). Essays on aesthetic education for the 21st century. Rotterdam, Netherlands: Sense Publishers.

Crispin, G.A. (1991). Who are lesson plans really for? NASSP Bulletin, 75, 112-114. 
Deporter, B., Reardon, M., \& Singer-Nourie, S. (1999). Quantum teaching. Needham Heights, MA: Allyn \& Bacon.

Dewey, J. (1934). Art as experience. New York, NY: Perigee Books.

Dewey, J. (1938). Experience in education. New York, NY: Simon and Schuster.

Duckworth, E. (2006). "The having of wonderful ideas" and other essays on teaching and learning. 3rd Ed. New York, NY: Teachers College Press.

Viereck, G. S. (1929, October 29). What life means to Einstein. The Saturday Evening Post, p. 117. Retrieved from http://www.saturdayeveningpost.com/wp-content/uploads/ satevepost/what_life_means_to_einstein.pdf

Eisner, E. W. (1967). Educational objectives: Help or hindrance? School Review, 75, 250266.

Eisner, E. W. (1985). The art of educational evaluation: A personal view. London: Falmer Press.

Eisner, E. W. (1994). Curriculum and cognition reconsidered. New York, NY: Teachers College Press.

Eisner, E. W. (2002) The educational imagination: On the design and evaluation of school programs (3rd Ed.). Upper Saddle River, NJ: Merrill Prentice-Hall.

Eisner, E. W. (Ed.). (2005). Reimagining schools: The selected works of Elliot W. Eisner. New York, NY: Routledge.

Gabler, I. C., \& Schroeder, M. (Eds.). (2003). Constructivist methods of the secondary classroom. Boston, MA: Pearson.

Gardner, H. (1983). Frames of mind: The theory of multiple intelligences. New York, NY: Basic Books.

Glatthorn, A. A. (1993). Teacher planning: A foundation for effective instruction. NASSP Bulletin. 77(1), 1-7.

Greene, M. (1988). The artistic-aesthetic and curriculum. Curriculum Inquiry, 6(4), 283-296.

Greene, M. (2001). Variations on a blue guitar. New York, NY: Teachers College Press.

Hall, S. (1991) Scopes. Unpublished Curriculum Unit.

Hill, J., Yinger, R., \& Robins, D. (1983). Instructional planning in a laboratory preschool. The Elementary School Journal, 83(3), 182-193.

Hunter, M. (1976). Improved Instruction. El Segundo, CA: TIP Publications.

Hunter, M. (1983). Mastery Teaching. El Segundo, CA: TIP Publications.

Hunter, M. (1984). Knowing, teaching, and supervising. In P. I. Hosford (Ed.), Using what we know about teaching. Alexandria, VA: ASCD.

Jackson, J. (2009). H2O and you. Science Activities, 46(1), 1-6.

Kellough, R. D., \& Kellough, N. G. (2008). Secondary school teaching: A guide to methods and resources. Upper Saddle River, NJ: Prentice Hall.

Lalik, R. V., \& Niles, J. A. (1990). Collaborative planning by two groups of student teachers. The Elementary School Journal, 90(3), 319-336.

Leinhardt, G. (1983). Novice and expert knowledge of individual students' achievement. Educational Psychologist, 18, 165-179.

Martin-Kniep, G. \& Uhrmacher, P. B. (1992). Teachers as curriculum developers. The Journal of Curriculum Studies, 24(3): 261-271.

Marzano, R. J., Pickering, D. J., \& McTighe, J. (1993). Assessing student outcomes: Performance assessment using the dimensions of learning model. Alexandria, VA: ASCD.

Marzano, R. J., Pickering, D. J., \& Pollock, J. E. (2001). Classroom instruction that works: Research-based strategies for increasing student achievement. Alexandria, VA: ASCD.

Moore, K. D. (2009). Effective instructional strategies: From theory to practice. Los Angeles, CA: Sage.

Morine, G. (1976). A study of teacher planning (BTES special study C). San Francisco: Far West Laboratory for Educational Research and Development. 
Moroye, C. M., \& Uhrmacher, P. B. (2009). Aesthetic themes and the art of teaching. Curriculum and Teaching Dialogue, $11(1 \& 2)$.

Moroye, C. M., \& Uhrmacher, P. B. (2010). Aesthetic themes as conduits to creativity. American Teacher Educators' Yearbook.

Oliver, D. W., \& K. W. Gershman. (1989). Education, modernity, and fractured meaning: Toward a process theory of teaching and learning. New York, NY: State University of New York Press.

Park, D. (1995). Combining satellite education and a STISE pedagogical model to enhance elementary science teaching in Korea and the United States (Unpublished master's thesis). University of Pennsylvania, West Chester, PA.

Perception. (n.d.). In Oxford English Dictionary online edition March 2011 (3rd edition). Retrieved from http://www.oed.com:80/Entry/140560.

Piaget, J. (1955). The stages of intellectual development in childhood and adolescence. In H. Gruber \& J. Voneche (Eds.), The Essential Piaget. Northvale, NJ: Jason Aronson.

Pinar, W., Reynolds, W., Slattery, P., \& Taubman P. (1995). Understanding curriculum. New York, NY: Peter Lang.

Popham, W., \& Baker, E. L. (1970). Systematic Instruction. Upper Saddle River, NJ: Prentice Hall.

Read, H. (1966). The redemption of the robot: My encounter with education through art. London, UK: Faber and Faber.

Renzulli, J. S. (1988). The multiple menu model for developing differentiated curriculum for the gifted and talented. Gifted Child Quarterly, 32, 298-309.

Robinson, K. (2006, June). Do schools kill creativity? [Video file]. Retrieved from http://www. ted.com/index.php/talks/ken_robinson_says_schools_kill_creativity.html

Roskos, K., \& Neuman, S. B. (1995). Two beginning kindergarten teachers' planning for integrated literacy instruction. Elementary School Journal, 96(2), 195-215.

Schmoker, M. J. (2006). Results now: How we can achieve unprecedented improvements in teaching and learning. Alexandria, VA: ASCD.

Schmuck, R., \& Schmuck, P. (1988) Group processes in the classroom. Dubuque, IA: W. C. Brown.

Schon, D. (1987). Educating the reflective practitioner. San Francisco, CA: Jossey-Bass.

Senges, M., Seely Brown, J., \& Rheingold, H. (2008). Entrepreneurial leaning in the networked age: How new learning environments foster entrepreneurship and innovation. Paradigms, 1, 125-140.

Serdyuko, P., \& Ryan, M. (2007). Writing effective lesson plans: The 5-star approach. Boston, MA: Pearson Allyn and Bacon.

Shaw, R. A., Pettigrew, J., \& van Nostrand, A. D. (1983). Tactical planning of writing instruction. The Elementary School Journal, 84(1), 45-51.

Skinner, B. F. (1938). The behavior of organisms. New York, NY: Appleton.

Spooner, F., Baker, J. N., Harris, A. A., Ahlgrim-Delzell, L., \& Browder, D. M. (2007). Effects of training in universal design for learning on lesson plan development. Remedial and Special Education, 28(1), 108-116.

Taba, H. (1962). Curriculum development, theory, and practice. Chicago, IL: University of Chicago Press.

Tyler, R. (1949). Basic principles of curriculum and instruction. Chicago, IL: University of Chicago Press.

Uhrmacher, P. B., Moroye, C., \& Conrad, B. (n.d.) Aesthetic dimensions of teaching and learning: Engage students differently. Retrieved from https://sites.google.com/site/crispaclassroom/ home

Uhrmacher, P. B. (2009). Toward a theory of aesthetic learning experiences. Curriculum Inquiry. 39(5), 613-636. 
Uhrmacher, P. B., Moroye, C., \& Conrad, B. (n.d.) Aesthetic dimensions of teaching and learning: Engage students differently. Retrieved from https://sites.google.com/site/crispaclassroom/ home

Vygotsky, L. S. (1931). The mind and society: The development of higher psychological processes. Cambridge, MA: Harvard University Press.

Walker, D. (2002). Fundamentals of curriculum: Passion and professionalism (2nd ed.). New York, NY: Routledge.

Waxman, H., Pardon, Y., \& Arnold, K. (2001). Effective instructional practices for students placed at risk of academic failure. In G. Borman, S. Stringfield, \& R. Slavin (Eds.), Title I: Compensatory education at the crossroads (pp. 201-223). New York, NY: Academic Press. Weiner, L. (1997). New teachers: Designing lesson plans: What new teachers can learn from Moffat and Wagner. The English Journal, 86(4), 78-79.

Wiggins, G. P. (1993). Assessing student performance. San Francisco, CA: Jossey-Bass Publishers.

Wiggins, G., \& McTighe, J. (2005). Understanding by design. Alexandria, VA: ASCD.

Yinger, R. (1979). Routines in teacher planning. Theory into Practice, 18(3), 163-169.

Yinger, R. (1980). A study of teacher planning. The Elementary School Journal, 80(3), 107127.

Zahorik, J.A. (1975). Teachers' planning models. Educational Leadership, 33(2), 134-139.

P. BRUCE UHRMACHER is Professor of Education and Coordinator of the Curriculum and Instruction program at the Morgridge College of Education, University of Denver. He is also the faculty advisor to the Aesthetic Education Institute of Colorado. His research interests include aesthetic education, curriculum theory and practice, and arts-based approaches to research. He is the Co-Editor for Curriculum and Teaching Dialogue journal, and Co-Editor of the book Beyond the One Room School.

BRADLEY M. CONRAD is an Assistant Professor of Education at Capital University. His research interests include culturally responsive teaching, curriculum, teacher education, and the arts in education. His most recent publication is the essay "The Power to Transform: Implementation as Aesthetic Awakening" in Essays on Aesthetic Education for the 21st Century.

CHRISTY M. MOROYE is an Assistant Professor of Educational Foundations and Curriculum Studies in the College of Education and Behavioral Sciences at the University of Northern Colorado, Greeley, Colorado. Her research interests include aesthetic and ecological perspectives of curriculum and teaching. She is the Associate Editor for Curriculum and Teaching Dialogue and recently published "Daydreams and Awakenings: A review of Fields of Green: Restorying culture, environment, and education" with Ben Ingman in Curriculum Journal. 